\title{
The Design of the College English Curriculum from the Perspective of International Engineering Education Accreditation-A Case Study from the Beijing Institute of Petrochemical Technology
}

\author{
Yaqin $\mathrm{He}^{1, *}$, Weiran Zhang ${ }^{1} \&$ Jiaolan Yan ${ }^{1}$ \\ ${ }^{1}$ Department of Foreign Languages, Beijing Institute of Petrochemical Technology, Beijing, China \\ *Correspondence: Department of Foreign Languages, Beijing Institute of Petrochemical Technology, No. 19 \\ Qingyuanbei Road, Huangcun, Daxing District, Beijing, China. E-mail: heyaqin@bipt.edu.cn
}

Received: December 15, 2020

Accepted: January 8, $2021 \quad$ Online Published: February 2, 2021

doi:10.5430/jct.v10n1p18

URL: https://doi.org/10.5430/jct.v10n1p18

\begin{abstract}
A scientific curriculum system is of vital importance for an institution's professional accreditation. This paper seeks to improve the previous College English curriculum by resolving certain recalcitrant problems impeding both teaching and learning; furthermore, it takes into account the demands of international society. By embracing an outcome-based, student-centered approach for International Engineering education accreditation, the paper emphasizes teaching targets of a College English curriculum for future engineers based on knowledge, capacity and quality. In addition, it provides a graduation requirement index matrix and, a differentiated curriculum system, which specifies a clear relationship between the system and students' outcomes. Finally, four characteristics of the system are elaborated: compulsory courses and optional courses are compared; English for General Purpose (EGP) and English for Special Purpose (ESP) are correlated; classroom teaching and extracurricular context are integrated; and formative assessment and summative assessment are combined.
\end{abstract}

Keywords: engineering education accreditation, outcome-based education, college english for non-english majors, curriculum systems

\section{Introduction}

China joined the Washington Accord on June 19, 2013. This agreement recognizes the substantial equivalence of the professional engineering training programs for four-year undergraduate majors certified by the contracting parties; the academic requirements and basic quality standards for the engineering profession are considered to be met for the graduates certified by the contracting party. In other words, the students' education, corresponding to China's Engineering Education Accreditation, will be accepted by other member states, and the graduates who have passed the certification will enjoy the same treatment as domestic graduates when applying for engineering qualification in the relevant countries. Wu Yan, director of the Higher Education Evaluation Center in the Chinese Ministry of Education, has asserted that engineering education accounts for one-third of the total number of higher education majors and graduates in China. The recognition of such a large group under the Washington Agreement not only lays the foundation for engineering students to "go global"; it also means that Chinese higher education, in general, will achieve worldwide acceptance (Jin, 2013). The "foreign language requirement" in the Engineering Education Accreditation Standards (revised November 2017), refers to "the ability to communicate effectively with industry counterparts and the public about complex engineering issues, including the writing of reports and designing of drafts and presentations, employing clear expression of and response to instructions, effectively entailing an international perspective, namely, the ability to communicate in a cross-cultural context." This requirement highlights the importance of foreign languages in the training of students in international engineering.

English, as a language employed virtually universally around the globe, provides language support for Chinese engineers to work outside of China and, hence, to engage in the exchange of information internationally. Accordingly, the quality of training in English is more central to the graduate's success than ever before. It is important, however, to acknowledge the perennial problem of poor student initiative and motivation (Xu, 2020). Teachers of College 
English in China traditionally are overworked, and their good impacts spread thin. Unless individually they appreciate that a crisis has confronted English teaching in China, Chinese teachers of English are less apt to be concerned about lowered professional standards (Tao, 2020). The lone teacher assessment (assessment by the teacher only) approach is time-consuming and discouraging, and it may not be very effective (Sun, 2018). Our university, Beijing Institute of Petrochemical Technology (BIPT) is no exception in having these problems. College English education focuses mainly on general English education, with a single curriculum. The graduates at BIPT report that they are unable to meet the demand for nuanced skills in speaking, writing and translating. More signally, the outcomes of teaching and learning at BIPT do not meet the requirements of International Engineering Education Accreditation for not only correct but effective English. How to devise a systematic college English curriculum system that integrates knowledge, accomplishment and ability development to meet the needs of society, schools and students remains a problem to be solved.

\section{The Basis of the Design of a College English Course System in Engineering Colleges}

\subsection{An Outline of the National, Medium and Long-term Plan for Education Reform and Development (2010-2020)}

In 2010, the Outline of the National Medium and Long-term Plan for Education Reform and Development (2010-2020) proposed the "cultivation of a large number of talents with international vision who are familiar with international rules and can participate in international affairs and international competition." "International talents" refer to students with broad international vision, profound professional knowledge, good cultural literacy and strong international communication ability. The cultivation of such talents is a systematic project of higher education in our country, and College English teaching is duty-bound to cultivate students' international vision, cultural literacy and cross-cultural communication skills.

\subsection{Guidelines on College English Teaching}

The Guidelines on College English Teaching issued by the Chinese Ministry of Education states that "the goal of college English teaching is to develop students' ability to use English, enhance their intercultural communication awareness and ability, and improve their comprehensive cultural literacy" (Wang, 2016). The Guidelines defines "curriculum" as "the concentrated expression of teaching objectives in the educational planning of a school, and...includes the arrangement and regulation of curriculum structure and curriculum content." The statement of the goal highlights the importance and necessity of effective teaching of College English. The fundamental task of engineering application-oriented universities is to cultivate application-oriented talents with strong practical, professional skills. This training goal determines that the curriculum goal of College English should focus on developing students' ability to communicate in English in a professional manner adequate for the high standards of international engineering communication.

Essential to designing the curriculum is to design the "curriculum system." The Guide proposes specific requirements for the curriculum system. These include dividing College English teaching and learning into three parts-general English, English for special purposes, and cross-cultural communication. College English courses consist of compulsory courses, required-elective courses, and optional courses; following the rules of language teaching and learning, colleges and universities should arrange corresponding teaching contents and periods reasonably, according to the type, level, source of students, orientation of running a school, and target of talent training, so as to form a dynamic, open, and scientific College English course system that reflects the features of the training programs of the university.

\subsection{Outcome-based Educational Concepts}

The certification standard of engineering education in China is oriented by students' learning output and evaluates the effectiveness of professional education against the core competence and quality requirements of graduates. In a 2015 training class for the China Engineering Education Accreditation, Zhou Aijun explained the teaching design of outcome-based education, based on the concept that "industry needs determine training objectives, which determine graduation requirements, which in turn determine the curriculum system, and the curriculum system determines the teaching content, teaching methods and teaching resources" (Zhou, 2015). 


\subsection{Postmodern Curriculum Theory}

The trend of curriculum theory development-from modern curriculum theory to a postmodern one-provides a guide for the reform of the college English curriculum system in engineering colleges. The traditional Taylor principle regards curriculum as a purpose, emphasizing a closed curriculum, while post-modern curriculum theory expert W. Doll believes that curricula are generated in the process of meeting various needs of the society, rather than being defined in advance (Zhong, 2008). The design of the English curriculum system should reflect "4R" principles: they should be rich, recursive, relational and rigorous. This theory emphasizes the dynamic and uncertain nature of curricula. It rejects any absolute, integral and unified standard, and it advocates diversified curricula. In addition, an American scholar, Posner G.J, proposes that curricula in whatever the particular social historical situation are the products of particular people working together, and they require making a series of particular technical, economic and political decisions. Curriculum development should consider five stakeholders: students, teachers, and social and environmental experts, as well as experts in the curriculum process and in turn all five interact with and are influenced by one another. According to Posner, both teachers and students need to be active participants in curriculum development (Posner, 2005).

\subsection{The Integrated Educational Concept of EGP and ESP}

At present, EGP is still the main subject of English teaching and learning in most engineering colleges. The same teaching objective, learning content, teaching modes and unified teaching materials may lead to the lack of individualized training of students who can't meet particular professional and/or employment needs. It is obvious that EGP teaching cannot meet the needs of engineering English talents for engineering professional certification. It is necessary to combine EGP teaching and ESP teaching effectively in the college English teaching curriculum. EGP and ESP are complementary. With profound knowledge and ability of EGP, it is easy for students to learn ESP. Similarly, in the ESP learning process, students not only gain professional knowledge, but also strengthen their basic English capabilities.

\section{The Design of the Course System of College English in Engineering Colleges}

\subsection{The Realization Matrix of College English Training Objectives and Graduation-requirements Index Points}

Here we present the curriculum goals of College English and the realization matrix of graduation-requirements index points.

With regard to the realization matrix of College English training objectives and graduation-requirements index points, our college has made the teaching plan of College English in accordance with the graduation requirements of students; the curriculum goals (Table 1) are based on the coordinated development of application-oriented talents in knowledge, ability and quality, and the realization matrix of graduation-requirements index points (Table 2) are according to the certification requirements of engineering specialty. All of these are characterized by being outcome-based, student-centered, engineering majors-focused, and local service-oriented, and they have been made with the help of subject experts and industry professionals to achieve the purpose of developing our college into a highly competitive application-oriented university. 
Table 1. The Curriculum Goals of College English

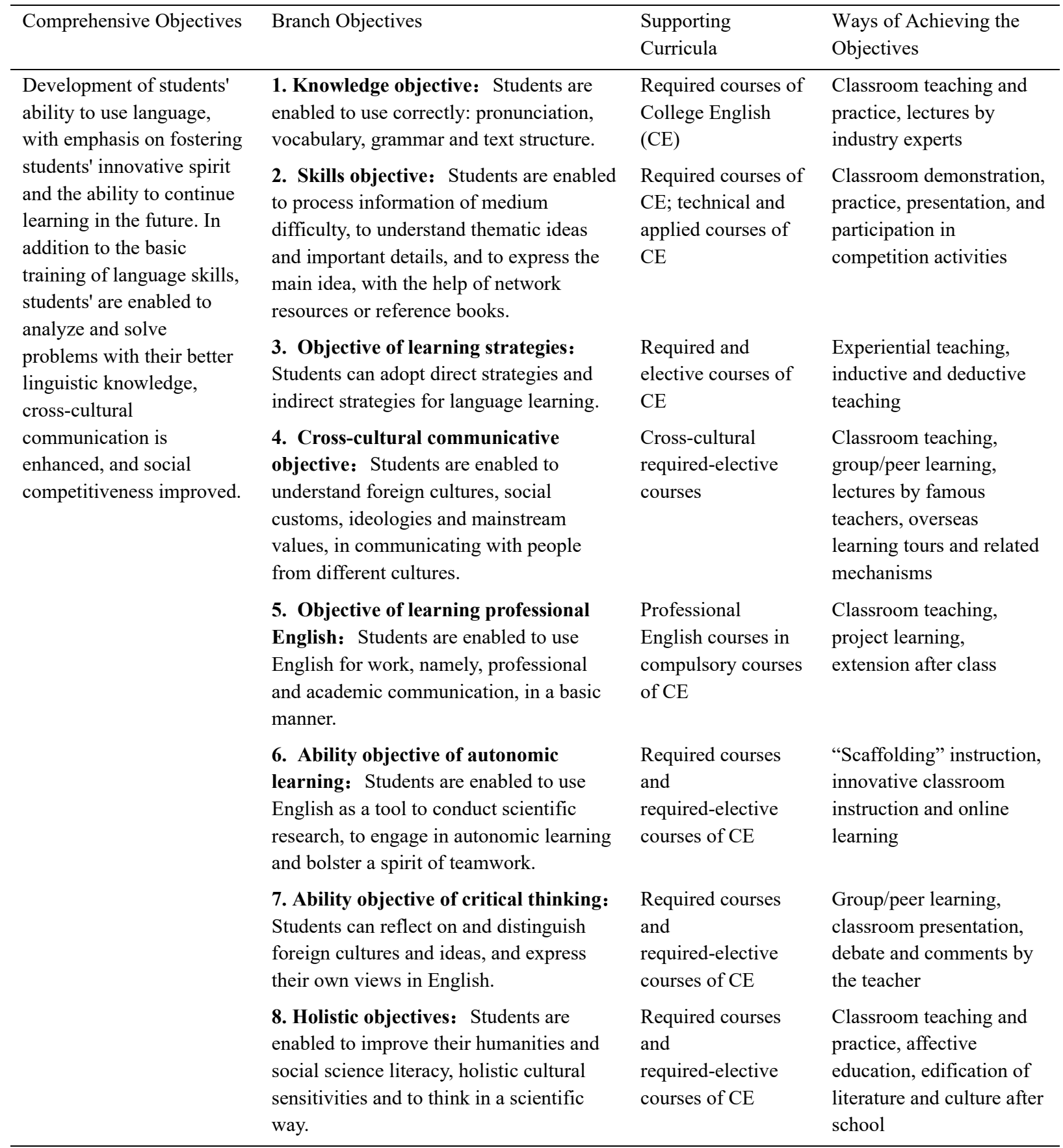


Table 2. The Realization Matrix of Graduation-Requirements Index Points

\begin{tabular}{|c|c|c|}
\hline $\begin{array}{l}\text { Graduation } \\
\text { Requirement Index } \\
\text { Points }\end{array}$ & $\begin{array}{l}\text { Curriculum } \\
\text { Objectives }\end{array}$ & Ways of Achieving the Objectives \\
\hline $\begin{array}{l}10.2 \text { Students are able } \\
\text { to use at least one } \\
\text { foreign language to read } \\
\text { the professional } \\
\text { literature materials in } \\
\text { that language, or to use } \\
\text { technical language to } \\
\text { communicate and } \\
\text { express themselves in a } \\
\text { cross-cultural } \\
\text { environment. }\end{array}$ & $\begin{array}{l}\text { Curriculum } \\
\text { Objectives } \\
1,2,3,4,5, \\
7,8\end{array}$ & $\begin{array}{l}\text { Pre-class assignments: List the assignments of key words and phrases, text-learning } \\
\text { materials and other audio-visual materials and send to the students before class by } \\
\text { WeChat and Mesotech, etc. } \\
\text { Explaining in class and illustrating in newly-created context: The teacher creates } \\
\text { learning situations based on real tasks to guide the students' inquiry-based learning, } \\
\text { collaborative learning and personalized activities. } \\
\text { Group (Peer)activities: Assign the topic of the teaching material as a group } \\
\text { assignment to be completed after class. } \\
\text { Class presentation: } 3-5 \text { minutes for each group report. } \\
\text { Peer learning: In class, the groups comment on each others' input and propose } \\
\text { suggestions for improvement. } \\
\text { Teachers' comments: On the basis of peer evaluation, the teacher makes } \\
\text { comprehensive comments and guides students to conduct deeper learning in order to } \\
\text { achieve teaching goals. } \\
\text { Works: Students revise the works displayed in class for further processing and } \\
\text { refinement; for the oral-output activity, they write the script after class and then } \\
\text { record the video. } \\
\text { Lectures by famous teachers: Regularly invite famous teachers from home and abroad } \\
\text { into the classroom to broaden students' academic and international horizons. } \\
\text { Lectures by professional experts: Regularly invite professional experts into the } \\
\text { classroom, so that teachers and students understand the demand standards of industry } \\
\text { talents and ways to achieve them. } \\
\text { Cross-cultural communication: Conduct cultural exchange with foreign students and } \\
\text { teachers; send students abroad for study and exchange. }\end{array}$ \\
\hline $\begin{array}{l}\text { 12.1 Students have a } \\
\text { correct understanding of } \\
\text { the necessity and } \\
\text { importance of self- } \\
\text { learning, and they are } \\
\text { aware of independent } \\
\text { learning and lifelong } \\
\text { learning. }\end{array}$ & $\begin{array}{l}\text { Curriculum } \\
\text { Objectives } \\
3,6,7,8\end{array}$ & $\begin{array}{l}\text { On-line learning: Complete online learning tasks by experiential learning as to find } \\
\text { out their own suitable learning methods and develop lifelong learning habits. } \\
\text { Second-class activities and competition: All students are required to participate in the } \\
\text { second-class activities such as the Festival of Foreign Culture and Art or at least one } \\
\text { competition activity to form a clear recognition of self-learning ability and language } \\
\text { practice ability. }\end{array}$ \\
\hline
\end{tabular}

\subsection{Diversified Teaching Objectives and Curriculum}

"Three-level objectives and three requirements" in Guidelines on College English Teaching serve, as a clear guideline for the needs of graded teaching of College English. Our college aims to base itself on the educational guidelines of the capital city, using therefore a model proven to have set a high standard for China's educational needs. Accordingly, the diversified teaching objectives have been set forth for the sake of the students and their English proficiency as well as of their professional training goals.

In order to guide students to be "lifelong English learners," while improving the English curriculum for the lower-grades, teachers are actively encouraged to exploit their own advantages in scientific research to offer elective courses of College English, so as to create a differentiated and three-dimensional college English curriculum system. 
Table 3. Differentiated and Three-dimensional Curriculum System of College English

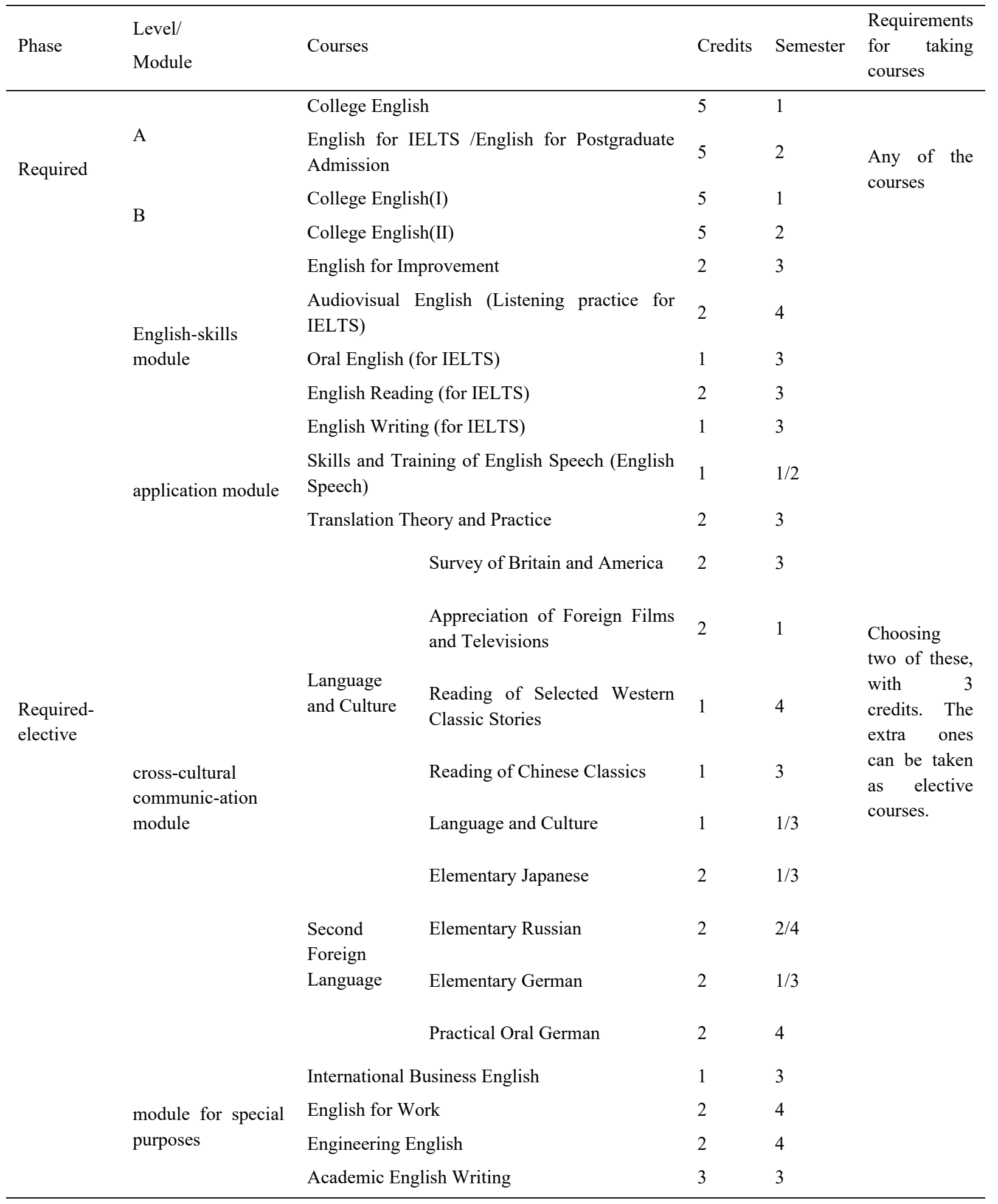


Table 4. The Three-dimensional Curriculum of Grading, Classification and Distribution for Required Courses

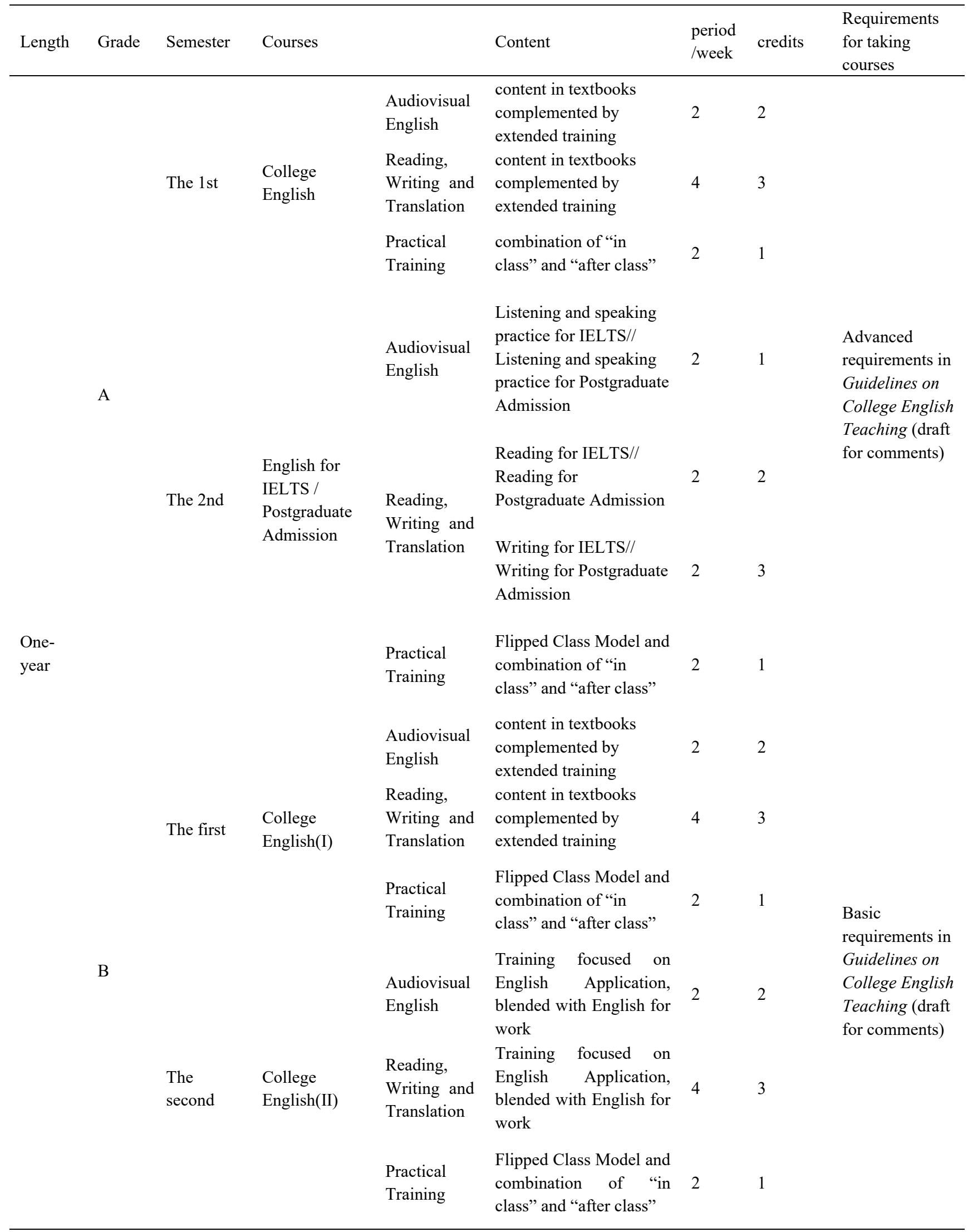


As Table 3 and Table 4 show, based on the three-dimensional curriculum idea of grading, classification and distribution College English courses have been adjusted for the three-dimensional curriculum: two phases (required courses and required elective courses), two grades (class A and class B), four modules (English-skills class module, application module, cross-cultural communication module, class module for special purposes), and various other courses (audio-visual, practical training, reading, writing and translation).

\subsection{A Multi-dimensional, Dynamic Evaluation System}

The concept of outcome-based education requires the reverse design of the College English curriculum. According to the teaching objectives of the course, our school formulates the assessment objectives, which guide us in determining the teaching methods and means and tracking the whole learning process of the students, thus strengthening the formative assessment. The result is a multi-dimensional dynamic assessment design. Table 5 shows an objective evaluation matrix of College English.

Table 5. Objective Evaluation Matrix of College English

\begin{tabular}{|c|c|c|c|c|}
\hline $\begin{array}{l}\text { Grade } \\
\text { Composition } \\
\text { Ratio } \\
\end{array}$ & Assessment/Evaluation & $\begin{array}{l}\text { Full } \\
\text { credit }\end{array}$ & $\begin{array}{l}\text { Detailed Rules for } \\
\text { Assessment/Evaluation }\end{array}$ & $\begin{array}{l}\text { Corresponding } \\
\text { Objectives }\end{array}$ \\
\hline \multirow{6}{*}{$\begin{array}{l}\text { Usual } \\
\text { Performance } \\
40 \%\end{array}$} & \multirow{3}{*}{ Written assignment } & \multirow{3}{*}{7} & Quiz in class & $1,2 、 3 、 5$ \\
\hline & & & & \\
\hline & & & Writing, translation and report & $2,3,4,5,6$ \\
\hline & Classroom activities & 20 & $\begin{array}{l}\text { Classroom presentation, group } \\
\text { discussion, peer evaluation and } \\
\text { inquiry-based learning }\end{array}$ & $\begin{array}{l}1 、 2 、 3 、 4 、 6 、 \\
7\end{array}$ \\
\hline & Autonomic learning & 8 & $\begin{array}{l}\text { Pre-class learning and autonomic } \\
\text { learning online after class }\end{array}$ & $1 、 2 、 3 、 5$ \\
\hline & Activities after class & 5 & $\begin{array}{l}\text { Competition and Culture-Day } \\
\text { activities, etc. }\end{array}$ & $2 、 4,6 、 7$ \\
\hline $\begin{array}{l}\text { Oral } \\
\text { Exam } 10 \%\end{array}$ & $\begin{array}{l}\text { TEP Oral ( Test for } \\
\text { English Proficiency) }\end{array}$ & 10 & TEP Level C ; TEP Level B & $1,2 、 3 、 4$ \\
\hline $\begin{array}{l}\text { Final Written } \\
\text { Exam } \\
(50 \%)\end{array}$ & $\begin{array}{l}\text { Comprehensive } \\
\text { application }\end{array}$ & 50 & $\begin{array}{l}\text { Comprehensive ability of listening, } \\
\text { reading comprehension, translation } \\
\text { and writing. }\end{array}$ & $\begin{array}{l}1 、 2 、 3 、 4 、 6 、 \\
7\end{array}$ \\
\hline
\end{tabular}

\section{The Connotation of Curriculum System of College English in Engineering Colleges}

College English courses in engineering colleges consist of the following modules: a general English-skills module, an English-application module, a module for special purposes and a module for cross-cultural communication module (language and culture, the second foreign language). The general English module consists of Reading and Writing, Listening and Speaking College English, Skills and Training in English Speech, and Translation Theory and Practice. The content of each course completes the tasks of improving students' basic skills, including vocabulary, grammar, listening and speaking, and writing and translation, and stimulates students' abilities, characterized as a thirst for knowledge and lifelong learning, leading students to adopt proper strategies and the means to engage in written communication, oral expression and interpersonal communication in a foreign language.

The training module of cross-cultural communication aims to broaden students' field of vision of other cultures and improve their humanistic quality. Its main purpose is to promote cross-cultural understanding and increase students' ability to engage in cross-cultural communication. These kind of courses for learners possess both an instrumental value and an intrinsic value, and they can also serve well cultural exchanges between China and foreign countries as well as advancing the strategy of Chinese cultures going out. This module consists of the following courses: Survey of Britain and America, Appreciation of Foreign Films and Televisions, Reading of Selected Western Classic Stories, Reading of Chinese Classics, Language and Culture, Elementary Japanese, Elementary Russian, Elementary German, Practical Oral German. These courses provide students with a better understanding of foreign history and culture, equip students with the ability to develop a global development concept and critical thinking, and enhance their international vision, humanistic quality and spirit of teamwork. 
Scientists and engineers in modern society need to be able to use English not only for daily communication, but also for expanding their facility in related academic tasks, such as writing reports and papers in English, and presenting research results in English at international conferences. The module consists of International Business English, English for Work, Engineering English and Academic English Writing, and aims to enable students to master written communicative skills in English and oral and interpersonal communicative skills, on the way toward becoming high-tier engineers in possession of a solid professional theoretical foundation and a holistic sensibility, as well as the necessary practical engineering skills, and the ability to communicate fluently.

\section{The Characteristics of Curriculum System of College English in Engineering Colleges}

\subsection{The Coordination of Compulsory Courses and Optional Courses}

The design of the College English curriculum includes compulsory courses and elective courses (given simultaneously), which provides diversified choices for students. It not only ensures that there are enough basic English courses for students, but it also enables students to conduct personalized and selective learning according to their English proficiency and their individual interests. The curriculum allows students to take extended College English courses from the first year until the senior year, depending on their individual situation. This continuous and progressive parallel-course system can help students improve their English proficiency continuously just as it, also, assists them in obtaining their desired employment.

\subsection{The Effective Connection between EGP and ESP}

The curriculum of our school encourages teachers to integrate students' professional vocabulary and terms into their teaching, adopt content-based Instruction and the flipped classroom teaching concept, and guide students to combine foreign language learning with their professional knowledge. After class, students will consult relevant English academic journals and literature to understand the academic frontier and the latest trends of their major. They are encouraged to make presentations in class to further improve their English learning motivation and lay a solid foundation for further improvement of English. The teacher sets up a separate ESP learning column according to the characteristics of students' majors in the class, such as asking students to present their professional learning experience in English or the latest progress in the particular field of professional knowledge, or to recreate a workplace scene in which other students are invited to complete tasks, make presentations and study in groups.

\subsection{The Integration of Extracurricular Context with Classroom Teaching}

The curriculum system gives play to the function of education by the extracurricular practice and promotes the application of the outcome-based education model. Based on the Standards of International Engineering Professional Certification, the extracurricular plan matches the ability promotion in class required by professional certification. The innovation credit system is built up, and the extracurricular activities are incorporated organically into the support system for the graduation requirements of undergraduates by means of a Foreign Cultures Festival, an English Speech Contest, a Translation Contest, an English Writing Competition based on the Internet and mobile learning platforms, an English Reading Contest, and a Film Dubbing Competition. These activities realize simulated scenes of communications in the classroom, linking in-class with after-class and virtual teaching with in-class teaching. These, in turn, prompt students to put in practice what they have learned in class and to grow into high-quality talents with practical, reflexive and creative capabilities.

\subsection{The Combination of Formative Assessment and Summative Assessment}

When evaluating the students' English learning results, the ratio of the formative assessment is increased in evaluation and the individual student's performance in the whole learning process is tracked and assessed. The formative assessment can ensure students meet the course requirements. With the aid of computer software, the reliability and validity of the examination paper is tested by statistical analysis, and the test results are tracked and studied. These reports of data and analysis are conducive to timely acquisition of teaching feedback data, hence to improvement of teaching methods, and furthermore, to the continuous improvement of teaching and learning quality. At the same time, the regular evaluation mechanism is maintained and continuously improved, by which the training objectives, graduation requirements and teaching links are regularly evaluated. Teachers play a major role in this continuous improvement, and the effect of continuous improvement is reflected by the students' learning outcomes. 


\section{Conclusion}

The report of the $19^{\text {th }}$ National Congress of the Communist Party of China states that: "We should foster a large number of talents at the international level, young promising people in science and technology and high-level innovation teams." Accordingly, the diversified, three-dimensional course system of College English is designed according to the Standards of Engineering Education Accreditation, with the talents training goal of the school in mind, as well as the demands of the society and of individual students self-assessment. This diversified, three-dimensional course system provides students with a variety of choices, intending to make them meet the requirements of international engineering capabilities. We believe that coordination of compulsory and optional courses along with integration of extracurricular context and classroom teaching helps to promote the initiative and increase motivation of students; the effective connection of EGP and ESP allows students to enjoy more opportunities to practice in simulated working situations. The combination of formative assessment and summative assessment forms a good new perception of assessment, encouraging both students and teachers to easily discover their weaknesses and make timely adjustments.

Various curriculum elements coordinate with each other, so that the original single, local elements are linked and formed into a whole. The design of the current curriculum system is still in the initial stage of exploration. It should rely on the organization and coordination of the authority in the school so as to provide a dynamic, open, scientific, reasonable, interdisciplinary, cross-departmental curriculum system of College English.

\section{Acknowledgements}

I would like to thank Dr. Jonathan Kaplan for his proofreading that helped improve earlier drafts of this article. My sincere gratitude also goes to the sponsor of the study, Beijing Education Committee (project number: SM202010017004) and the reviewers of Journal of Curriculum and Teaching for their comments and suggestions for revisions.

\section{References}

China Engineering Education Accreditation Association. (2020). Criteria of Engineering Education Accreditation (revised in Dec. 2019). Retrieved from http://cec.hrbeu.edu.cn/2020/0115/c9425a247842/page.htm

International Engineering Alliance. (2020). Washington Accord. Retrieved from https://www.ieagreements.org/accords/washington/

Jin, H-T. (2013). What Does Engineering Education Accreditation Really Mean? Guangming Daily, November, 27.

Posner, G. J. (2005). Analyzing the Curriculum. Xi'an: Shaanxi Normal University Press.

Sun, S-G., \& Wen, Q-F. (2018). Teacher-student Collaborative Assessment (TSCA) in Integrated Language Classrooms. Indoneslan Journal of Applied Linguistics, 8(2), 369-379. https://doi.org/10.17509/ijal.v8i2.13301

Tao, W-H., \& Lv, H-B. (2020). A Practical Research on the Construction of College English Extended Curriculum System and Professional Development of Foreign Language Teachers. Guiding Journal of Science and Education, 32, 81-83.

Wang, S-R. (2016). The Elucidation of Guidelines on College English Teaching. Foreign Language World, 2016(3), $2-10$.

Xi, J-P. (2017). The 19 th National Congress of the Communist Party of China Report. Retrieved from http://www.12371.cn/2017/10/27/ARTI1509103656574313.shtml

$\mathrm{Xu}, \mathrm{H}-\mathrm{N}$. (2020). Constructing College Englsih Curriculum System Based on the OBE Idea. Journal of HUBEI Open Vocational College, 33(22), 176-177.

Zhong, Q-Q. (2008). Curriculum Logic. Shanghai: East China Normal University Press.

Zhou, A-J. (2015). Concepts and Characteristics of Engineering Education Accreditation. Retrieved from https://wenku.baidu.com/view/6ccefc5850e2524de4187e57.html 


\section{Copyrights}

Copyright for this article is retained by the author(s), with first publication rights granted to the journal.

This is an open-access article distributed under the terms and conditions of the Creative Commons Attribution license (http://creativecommons.org/licenses/by/4.0/). 